\title{
Efektivitas Pengelolaan BUMDes Sataretanan dalam Meningkatkan Pendapatan Asli Desa
}

\author{
*Romaiki Hafni ${ }^{1, a}$, Affan ${ }^{2, ~ b}$, M. Naulul Hakiki ${ }^{3}$ \\ 1) Institut Ilmu Keislaman Annuqayah (INSTIKA) Guluk-Guluk Sumenep Jawa Timur Indonesia \\ ${ }^{2)}$ Institut Ilmu Keislaman Annuqayah (INSTIKA) Guluk-Guluk Sumenep Jawa Timur Indonesia \\ ${ }^{2)}$ Institut Ilmu Keislaman Annuqayah (INSTIKA) Guluk-Guluk Sumenep Jawa Timur Indonesia

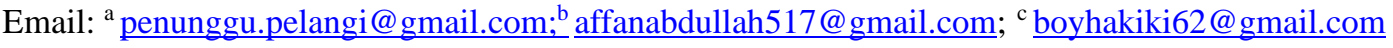

\section{DOI:}

Cara Mensitasi Artikel ini:

https://doi.org/10.469 Hafni, R., \& Affan, A., Hakiki, M. N. (2021). Efektivitas pengelolaan BUMDes

63/jam.v4i2.414 Sataretanan dalam meningkatkan pendapatan asli desa. AL-Muqayyad, 4(2), 98-107. https://doi.org/10.46963/jam.v4i2.414

\section{Keywords:}

Effectiveness, BUMDes

Management, Village

Original Income.

\section{Kata Kunci:}

Efektivitas,

Pengelolaan

BUMDes,

Pendapatan Asli

Desa.

\section{Informasi Artikel:}

Diterima:

07/11/2021

Direvisi:

Diterbitkan

30/12/2021

\section{*Corresponding}

Author

penunggu.pelangi@g $\underline{\text { mail.com }}$

\section{ABSTRACT}

The purpose of this article is to determine the management strategy of the Sataretanan BUMDes and to analyze the effectiveness of the Sataretanan BUMDes in increasing Village Original Income. Data collection techniques using observation, interviews, and documentation. The data analysis technique is descriptive analysis. The results of the management strategy research carried out by BUMDes Sataretanan held regular meetings of BUMDes internal members to evaluate the entire development of the BUMDes Management Program, formed business groups from each hamlet that were members of the SDS business group (Soddara Dhelem Sataretanan), held entrepreneurship training and product production assistance. establish cooperation with DPMD, Department of agriculture and plantations, Disperindag and Disnakertrans. The effectiveness of the Sataretanan BUMDes management has not been effective because it has not met all indicators of effectiveness. Of the three indicators that are used as analytical tools, namely goal achievement, integration, and adaptation, only one can be met, namely the integration indicator

\section{ABSTRAK}

Tujuan arikek ini untuk mengetahui strategi pengelolaan BUMDes Sataretanan dan untuk menganalisis efektivitas BUMDes Sataretanan dalam meningkatkan Pendapatan Asli Desa. Teknik pengumpulan data menggunakan observasi, wawancara dan dokumentasi. Teknik analisis datanya dengan analisis-deskriptif. Hasil penelitian strategi pengelolaan yang dilakukan oleh BUMDes Sataretanan mengadakan pertemuan rutin anggota internal BUMDes untuk mengevaluasi seluruh perkembangan Program Pengelolaan BUMDes , membentuk kelompok usaha dari masing-masing dusun yang tergabung dalam kelompok usaha SDS (Soddara Dhelem Sataretanan), mengadakan pelatihan kewirausahaan dan pendampingan produksi produk, menjalin kerjasama dengan DPMD, Dinas pertanian dan perkebunan, Disperindag dan Disnakertrans. Efektivitas pengelolaan BUMDes Sataretanan belum efektif karena belum memenuhi semua indikator efektifitas. Dari tiga indikator yang dijadikan pisau analisis yaitu pencapaian tujuan, integrasi dan adaptasi, hanya satu yang dapat dipenuhi yaitu indikator integrasi. 
Efektivitas Pengelolaan BUMDes Sataretanan dalam Meningkatkan Pendapatan Asli Desa

\section{PENDAHULUAN}

Indonesia merupakan sebuah Negara yang kaya raya dan subur, kekayaan alamnya sangat melimpah dari sabang sampai merauke. Dengan kekayaan alam tersebut mampu mencukupi segala kebutuhan masyarakat. Setiap wilayah dan desa memiliki potensi atau hasil alam yang berbeda-beda, dimana potensi alam tersebut dimanfaatkan untuk memenuhi kebutuhan sehari-hari atau meningkatkan taraf kehidupan perekonomian keluarga.

Pembangunan Desa hakekatnya merupakan basis dari pembangunan Nasional, karena apabila setiap desa telah mampu melaksanakan pembangunan secara mandiri maka kemakmuran masyarakat akan mudah terwujud dan secara Nasional akan meningkatkan indeks kemakmuran masyarakat Indonesia. Desa merupakan sentral bagi perekonomian Negara karena segala kebutuhan Negara ditopang oleh desa, yakni hasil alam yang melimpah dan dapat membantu perputaran ekonomi sebuah Negara. Dengan demikian agar tetap menstabilkan perputaran ekonomi di sebuah desa, pemerintah desa membentuk lembaga ekonomi yaitu Badan Usaha Milik Desa (BUMDes). Dengan adanya BUMDes semua pengelolaan sebuah desa dapat dengan mudah untuk dipantau.

BUMDes merupakan lembaga yang berada dibawah naungan desa. Hal ini dibentuk untuk memberikan kontribusi besar terhadap PAD (Pendapatan Asli Desa) atau masyarakat desa pada umumnya. Desa Soddara Kecamatan Pasongsongan Kabupaten Sumenep memiliki potensi alam yang sangat melimpah baik dari sektor pertanian, perkebunan dan lahan yang berpotensi untuk dijadikan sebuah wisata, maka berdirilah BUMDes Sataretanan yang dapat mengkoordinir segala kegiatan masyarakat dan dapat membantu segala kegiatan yang berkaitan dengan wirausaha.

BUMDes Sataretanan Desa Soddara Kecamatan Pasongsongan Kabupaten Sumenep memiliki visi misi besar untuk membangun kemandirian desa dalam sektor ekonomi. Berdirinya BUMDes Sataretanan merupakan langkah awal menuju desa mandiri, karena bumdes sataretanan sudah memiliki banyak program unggulan yang prospek kedepannya dapat membantu perekonomian desa serta dapat memberikan kontribusi ke pendapatan asli desa (PAD). namun demikian masih banyak problem ataupun kendala dari beragam aspek sehingga pengelolaannya belum maksimal.

Adapun problem yang dihadapi BUMDes Sataretanan antara lain: mulai dari internalnya yaitu kurangnya kesadaran bagi para anggota bumdes akan tanggungjawabnya sehingga hal ini berdampak kurang efektif bagi pengelolaan BUMDes. Di sisi yang lain, tidak adanya modal yang memadai untuk menjalankan usaha dan membeli alat-alat produksi. Dari aspek SDM, Tidak adanya mentor untuk melatih dan menggali skill SDM sehingga hal itu berdampak negatif terhadap peningkatan pendapatan asli desa.

Selain itu Kurangnya pengoptimalan hasil alam desa menyebabkan hasil panen tidak dijadikan lahan bisnis untuk kemudian diolah menjadi produk unggulan melainkan diijual secara mentah ke pasar bebas pastinya dengan harga yang sangat murah.

\section{Al-Muqayyad}

Vol 4 No 2 (2021) 
Salah satu upaya yang dilakukan BUMDes Sataretanan dalam mewujudkan kemandirian Desa adalah dengan membentuk kelompok UMKM yang disebut dengan istilah SDS (Soddara Delem Sataretanan) sebagai mitra BUMDes. SDS ini merupakan kelompok UMKM yang sengaja dibentuk untuk menampung semua produk yang dihasilkan oleh masing-masing Dusun di Desa Soddara. Produk tersebut kemudian dipasarkan baik ke pasar tradisional atau pasar modern. Dengan adanya SDS sebagai mitra BUMDes Sataretanan, dapat saling menguntungkan baik dari pihak Dusun atau bagi SDS sendiri. SDS ini menaungi segala kebutuhan yang dihasilkan oleh dusun untuk membuat pruduk baik dari peizinan layak konsumsi atau perizinan peredaran ke pasar luas.

Dari berbagai permasalahan diatas, penulis tertarik untuk meneliti lebih lanjut tentang efektivitas pengelolaan BUMDes Sataretanan dalam meningkatkan Pendapatan Asli Desa. Penelitian ini akan menfokuskan pembahasannya pada persoalan Bagaimana strategi pengelolaan BUMDes Sataretanan di Desa Soddara Pasongsongan Sumenep? dan Bagaimana Efektivitas pengelolaan BUMDes Sataretanan di Desa Soddara Pasongsongan Sumenep dalam meningkatkan Pendapatan Asli Desa?

\section{METODE}

Penelitian sangat perlu dilakukan pendekatan penelitian, agar penelitian yang dilakukan dapat berjalan dengan baik dan sistematis. Metode penelitian yang digunakan yaitu metode deskriptif analisis. Dengan pendekatan kualitatif karena penelitian ini bertujuan memperoleh pemaparan yang objektif dan mengungkapkan gambaran masalah yang terjadi pada saat penelitian ini berlangsung khususnya mengenai Efektivitas Pengelolaan BUMDes dalam meningkatkan Pendapatan Asli Desa. Penelitian ini dilakukan di BUMDes Soddara Kec. Pasongsongan Kab. Sumenep. Penelitian ini berlangsung kurang lebih 1 bulan yaitu pada bulan September 2021.

Dalam melakukan penelitian ini data-data yang diperlukan di peroleh dari dua sumber yaitu: Data primer dan Data Sekunder. Data merupakan data yang diperoleh dari sumbernya secara langsung, diamati dan dicatat secara langsung, seperti wawancara, observasi dan dokumentasi. Adapun data sekunder yaitu data yang diperoleh dari data yang sudah ada dan mempunyai hubungan masalah yang diteliti yaitu meliputi literaturliteratur yang ada.

Untuk menghimpun data, penelitian ini menggunakan teknik observasi, wawancara dan dokumentasi. Data yang sudah terkumpul melalui teknik pengumpulan data untuk kemudian diolah dengan menempuh langkah-langkah pengolahan data sebagai berikut: mengumpulkan data hasil observasi dan wawancara, Menginterpretasi data hasil observasi dan wawancara, Mendeskripsikan data hasil observasi dan wawancara untuk menjawab rumusan masalah penelitian dan Menarik kesimpulan data hasil observasi dan wawancara untuk menjawab rumusan masalah penelitian. 


\section{HASIL DAN PEMBAHASAN}

Efektivitas menekankan pada hasil yang dicapai, sedangkan efesiensi lebih melihat pada bagaimana cara mencapai hasil yang dicapai itu dengan membandingkan antara input dan outputnya (Siagaan 2001). Lebih lanjut menurut Agung Kurniawan dalam bukunya Transformasi Pelayanan Publik mendefinisikan efektivitas, sebagai berikut: "Efektivitas adalah kemampuan melaksanakan tugas, fungsi (operasi kegiatan program atau misi) dari pada suatu organisasi atau sejenisnya yang tidak adanya tekanan atau ketegangan diantara pelaksanaannya" (Kurniawan 2005). Dapat disimpulkan bahwa efektivitas adalah suatu ukuran yang menyatakan seberapa jauh target (kuantitas, kualitas dan waktu) yang telah dicapai oleh manajemen, yang mana target tersebut sudah ditentukan terlebih dahulu.

Efektivitas adalah suatu ukuran yang menyatakan seberapa jauh target (kuantitas, kualitas dan waktu) telah tercapai. Dimana makin besar persentase target yang dicapai, makin tinggi efektivitasnya (Hidayat 1986).

Menurut Mahmudi (2005:92) bahwa efektivitas merupakan hubungan antara output dengan tujuan, semakin besar kontribusi (sumbangan) output terhadap pencapaian tujuan maka akan semakin efektif organisasi, program atau kegiatan tersebut. Efektivitas berfokus pada outcome (hasil), program, atau kegiatan yang dinilai efektif apabila output yang dihasilkan dapat memenuhi tujuan yang diharapkan.

Efektivitas menurut Kurniawan (2005 :109) adalah kemampuan melaksanakan tugas, fungsi (operasi kegiatan program atau misi) daripada suatu organisasi atau sejenisnya yang tidak adanya tekanan atau ketengangan diantara pelaksanaanya. Sedarmayanti (2009 :59) mendefinisikan konsep efektivitas sebagai suatu ukuran yang memberikan gambaran seberapa jauh target dapat tercapai.

Menurut M Steers dalam edi sutrisno (2007:24) mengemukakan bahwa yang terbaik dalam meneliti efektivitas ialah memerhatikan secara serempak tiga buah konsep yang saling berkaitan: (1) optimalisasi tujuan-tujuan (2) perspektif system (3) tekanan pada segi perilaku manusia dalam susuan organisasi. Cara seperti ini disebut ancangan saja, misalnya hanay dari segi tujuan.

Richard M. Steers dalam Tangkilisan (2005) menggungkapkan ada 3 indikator dalam efektivitas. Ia mengatakan indikator efektivitas sebagai berikut:

1. Pencapaian tujuan

Pencapaian tujuan adalah keseluruhan upaya pencapaian tujuan harus dipandang sebagai suatu proses. Oleh karena itu, agar pencapaian tujuan akhir semakin terjamin, diperlukan pentahapan, baik dalam arti pentahapan pencapaian bagian-bagiannya maupun pentahapan dalam arti periodisasinya. Pencapaian tujuan terdiri dari 2 subindikator, yaitu: kurun waktu dan sasaran yang merupakan target.

\section{Al-Muqayyad}

Vol 4 No 2 (2021) 
2. Integrasi

Integrasi yaitu pengukuran terhadap tingkat kemampuan suatu organisasi untuk mengadakan sosialisasi atau komunikasi dan pengembangan konsensus. Integrasi menyangkut proses sosialisasi, dan partisipasi masyarakat.

3. Adaptasi

Adaptasi adalah kemampuan organisasi untuk menyesuaikan diri dengan lingkungannya. Berkaitan dengan kesesuaian pelaksanaan program dengan keadaan di lapangan serta sumber daya manusia.

Pengelolaan adalah suatu proses tertentu yang terdiri atas perencanaan, pengorganisasian, penggerakan, dan pengawasan yang dilakukan untuk menentukan dan mencapai tujuan tertentu dengan cara menggunakan manusia dan sumber-sumber lain (Moekijat 2000). Secara etomologi istilah pengelolaan berasal dari kata kelola dan biasanya merujuk pada proses mengurus atau menangani sesuatu untuk mencapai tujuan tertentu. Jadi pengelolaan merupakan ilmu manajemen yang berhubungan dengan proses mengurus dan menangani sesuatu yang mewujudkan tujuan tertentu yang ingin dicapai. Pengelolaan merupakan istilah yang dipakai dalam ilmu manajemen (Nugroho 2003).

Pengelolaan adalah suatu proses tertentu yang terdiri atas perencanaan, pengorganisasian, penggerakan, dan pengawasan yang dilakukan untuk menentukan dan mencapai tujuan tertentu dengan cara menggunakan manusia dan sumber-sumber lain (Moekijat 2000). Secara etomologi istilah pengelolaan berasal dari kata kelola dan biasanya merujuk pada proses mengurus atau menangani sesuatu untuk mencapai tujuan tertentu. Jadi pengelolaan merupakan ilmu manajemen yang berhubungan dengan proses mengurus dan menangani sesuatu yang mewujudkan tujuan tertentu yang ingin dicapai. Pengelolaan merupakan istilah yang dipakai dalam ilmu manajemen (Nugroho 2003). Selanjutnya pengelolaan sama dengan manajemen sehingga pengelolaan dipahami sebagai suatu proses membeda-bedakan atas perencanaan, pengorganisasian, penggerakan dan pengawasan dengan memanfaatkan baik ilmu maupun seni agar dapat menyelesaikan tujuan yang telah ditetapkan sebelumnya (Terry 2009).

Menurut Undang-Undang No. 6 Tahun 2014 tentang desa Badan Usaha Milik Desa, selanjutnta disebut BUM Desa adalah badan usaha yang seluruh atau sebagian besar modalnya dimiliki oleh Desa melalui penyertaan secara langsung yang berasal dari kekayaan Desa yang dipisahkan guna mengelola aset, jasa pelayanan dan usaha lainnya untuk sebesar-besarnya kesejahteraan masyarakat Desa.

Sementara menurut (Badriyadi 2012) mengemukakan bahwa Badan Usaha Milik Desa merupakan pilar perekonomian desa yang berfungsi sebagai lembaga sosial (sosial institution) dan komersial (commercial institution) yang berpihak pada kepentingan masyrakat serta mencari keuntungan.

Menurut Tim Pusat Kajian Dinamika Sistem Pembangunan Fakultas Ekonomi Universitas Brawijaya dalam bukunya yang berjudul Buku Panduan Pendirian dan 
Pengelolaan Badan Usaha Milik Desa (BUMDes) menyatakan bahwa: BUMDes merupakan pilar kegiatan ekonomi di desa yang berfungsi sebagai lembaga social (social institution) dan komersial (commercial institution). BUMDes sebagai lembaga social berpihak kepada kepentingan masyarakat melalui kontribusinya dalam penyediaan pelayanan sosial. Sedangkan sebagai lembaga komersial bertujuan mencari keuntungan melalui penawaran sumberdaya lokal (barang dan jasa) ke pasar. (Tim UPB: 2007: 3)

Menurut Peraturan Menteri Dalam Negeri (permendagri) Nomor 20 Tahun 2018 tentang Pengelolaan Keuangan Desa dalam bab 1 menjelaskan bahwa pendapatan merupakan semua penerimaan desa dalam 1 tahun anggaran yang menjadi hak desa dan tidak perlu dikembalikan oleh desa. Dalam pasal 11 Peraturan Menteri Dalam Negri (permendagri) Nomor 20 Tahun 2018 dijelaskan pula bahwa pendapatan desa terdiri atas kelompok: (a) Pendapatan asli desa; (b) Transfer; dan (c) Pendapatan lain-lain.

Kemudian dijelaskan secara rinci dalam permendagri Bab 3 Pasal 12 tentang Anggaran Pendapatan dan Belanja Desa (APBD) bahwa kelompok pendapatan asli desa terdiri atas: (1) Hasil usaha; (2) Hasil aset; (3) Swadaya, partisipasi dan gotong-royong dan (4) Pendapatan asli desa lain.

Letak geografis Desa Soddara kecamatan pasongsongan kabupaten sumenep terletak di ujung utara kecamatan pasongsongan, disebelah utara berbatasan dengan desa panaongan, disebelah timur berbatasan dengan ambunten barat dan desa duko, di sebelah selatan berbatasan dengan desa lebeng timur, dan desa lebeng Barat, dan dibelah barat berbatasan dengan kabupaten pamekasan.

Desa soddara memiliki luas wilayah $13 \mathrm{~km}$ persegi, yang memiliki 8(delapan) Dusun yaitu: dusun bungtrebung, dusun langgulang, dusun paowan, dusun gaber, dusun panyeppen, dusun serreh, dusun somper oloh, dusun somper pocok, dengan jumlah penduduk desa soddara tahun 2021 sebanyak 5177 jiwa. Desa soddara memiliki luas 13 $\mathrm{km}$ persegi dan berada di daerah dataran tinggi, dimana masyarakat $80 \%$ berprofesi sebagai petani selain dari itu sisanya ada yang mengelola batu alam yang berada di desa dan selain dari itu berprofesi sebagai pengusaha kecil kecilan. Selama ini sebagian besar akses permodalan masyarakat bersumber dari (cungrocung) yang dalam bahasa indonesianya ialah gotongroyong.

Pada tanggal 16 agustus 2016 berdirilah BUMDes yang dirumuskan oleh bapak Samsul Arifin selaku sekertaris Desa Soddara. berdirinya BUMDes ini berdasarkan kesadaran beliau terkait potensi alam yang ada di desa soddara. Sehingga muncullah ide untuk mendirikan BUMDes supaya seluruh hasil alam yang ada di desa dapat dijadikan lahan keuntungan tentunya hal ini akan kembali kepada masyaratak setempat. Pada awal mula berdirinya badan usaha milik desa ini bernama BUMDes Permai namun dengan berjalannya waktu bumdes permai diganti nama menjadi BUMDes Sataretanan hal ini di dasari atas arti dari kata TARETANAN (saudara) yang sangat senada dengan nama Desa. BUMDes Sataretanan memiliki beberapa usaha yang masih dalam tahap 
pembangunan dan perencanaan sehingga seluruh aktifitas yang ada didalamnya saat ini kurang berjalan dengan maksimal karena kurangnya modal. BUMDes Sataretanan telah memberikan kontribusi terhadap pendapatan asli desa meski jumlah angka yang disumbangkan tidak banyak.

Jumlah struktural kepengurusan BUMDes Sataretanan terdiri dari 1 penasehat yakni sekertaris desa, 3 orang pengurus BUMDes yakni ketua, sekretaris dan bendahara. dan 8 anggota yang terdiri dari warga desa.

Berikut adalah strategi pengelolaan yang dilakukan oleh BUMDes Sataretanan Desa Soddara Kecamatan Pasongsongan Kabupaten Sumenep:

Pertama, Mengadakan pertemuan rutin anggota internal BUMDes untuk mengevaluasi seluruh perkembangan Program Pengelolaan BUMDes Sataretanan. Penyelenggaraan Program Pengelolaan Badan Usaha Milik Desa (BUMDes) Sataretanan di Desa Soddara dimaksudkan agar pemerintah desa mampu mengelola perekonomian masyarakat, keuangan, pertanahan, dan potensi desa lainnya secara tepat, efektif, efisien, dan akurat serta dapat akuntabel.

Kedua, Membentuk kelompok usaha dari masing-masing dusun yang tergabung dalam kelompok usaha SDS (soddreh delem sataretanan). Dalam menanggulangi angka kemiskinan dan dapat mengoptimalkan perekonomian keluarga. Sehingga setiap dusun yang ada di desa soddara memiliki produk unggulan masing masing.

Ketiga, Mengadakan pelatihan kewirausahaan dan pendampingan produksi produk. Sehingga dapat mempermudah masyarakat dalam membangun sebuah usaha. Sasarannya yaitu agar setiap dusun yang memiliki potensi alam bias dijadikan bahan untuk diproduksi. Manfaat dari pelatihan kewirausahaan dan pendampingan adalah untuk memberikan kemudahan untuk Aparatur Desa da masyarakat Desa. Kemudahan yang dirasakan oleh Aparatur Desa adalah kemudahan dalam membina masyarakat sehingga akan mengurangi angka prasejahtera dan meminimalisir angka kriminal di masyarakat. Sedangkan kemudahan yang dirasakan oleh masyarakat adalah memperoleh kemudahan pada saat bertransaksi dan juga investasi.

Keempat, Menjalin kerjasama dengan DPMD, Dinas pertanian dan perkebunan, DIsperindag dan disnakertran, ini dilakukan agar segala aktivitas BUMdes beserta SDS selaku mitra BUMDes dapat menjalankan segala kegiatan yang dapat membantu perkembangan perekonomian Masyarakat Desa. Dan adanya Kerjasama dengan MES Sumenep terkait dengan eduksi manajemen bismis berbasis syariah.

Penyelenggaraan Program Pengelolaan Badan Usaha MIlik Desa (BUMDes) di Desa Soddara bertujuan untuk:

1. Peningkatan perekonomian desa untuk kesejahteraan masyarakat desa,

2. Pengoptimalan aset desa,

3. Meningkatkan pengelolaan potensi desa sesuai dengan kebutuhan masyarakat.

4. Mengurangi angka kemiskinan Kemeskinan

5. Memberikan pelayanan terhadap kebutuhan masyarakat desa. 
Pengelolaan BUMDes Sataretanan telah dikelola dengan cukup baik sesuai harapan masyarakat, hal ini dikarenakan sejak tahap awal berdirinya BUMDes Sataretanan sudah melibatkan masyarakat dan mendapatkan dukungan langsung dari masyarakat desa, pelaksanaan usaha BUMDes sedikit banyak telah membantu perekonomian masyarakat. dalam pengelolaannya kedepan BUMDes Sataretanan sedang merncanakan beberapa pembangunan dan usaha, yaitu: Pertama perencanaan pembangunan Kantor BUMDes sendiri, kedua merencanakan pembuatan dan pembangunan usaha Bukit Lanjari yang mana hal ini akan menjadi ciri has Desa Soddara kedepannya, Ketiga merancang unit usaha fotokopi sekaligus alat tulis kantor (ATK). Keempat serta pelayanan pemayaran pajak. Usaha-usaha BUMDes Sataretanan masih dalam tahap perencanaan sehingga tidak akan menghasilkan pendapatan bulanan atau pendapatan tahunan di tahun ini tahun 2021.

Untuk meningkatkan pemerataan kesejahteraan dan kemandirian ekonomi masyrakat pedesaan adalah dengan mengembangkan usaha kecil dan menengah disektor produksi, pengelolaan hasil alam yang melimpah dan perdagangan dengan memberikan akses permodalan dari berbagai investor yang dapat memberikan modal tambahan dan dapat menaungi usaha yang berada di masyarakat dalam rangka mendukung perekonomian masyarakat desa. Melalui kementrian desa pembangunan daerah tertinggal, pemerintah memberikan wewenang kepada pengurus desa untuk mengurus dan mengembangkan wilayah di pedesaan dan telah menetapkan strategi pembangunan eknomi desa melalui pembentukan lembaga yang disebut dengan Badan Usaha Milik Desa (BUMDes).

Pengukuran efektivitas yang Dikemukakan oleh Richard M. Steers dalam Tangkilisan (2005) menggungkapkan ada 3 indikator dalam efektivitas. Ia mengatakan indikator efektivitas sebagai berikut:

\section{Pencapaian tujuan}

Pemanfaatan sumber daya yakni SDA, SDM, serta sumber dana dalam pengelolaan BUMDes sataretanan belum efektif karena dalam pemanfaatan sumber daya manusia, BUMDes Sataretanan masih sangat terbatas.

Menurut data bagi hasil BUMDes yang penulis tela'ah bahwasanya BUMDes Sataretanan Desa Soddara terkait dengan Pendapatan Asli Desa masih kurang efektif sebab dari data yang ada BUMDes belum bisa mencapai target tahunan yang mana target anggaran BUMDes ke Pendaptan Asli Desa yaitu sebesar Rp 5.000.000, namun yang disumbangkan pada tahun 2021 hanya berjumlah Rp 2.000.000.

Sementara itu, Hasil aset desa yang didalamnya itu ada aset yang dimiliki desa dan disewakan ke masyarakat seperti TKD (Tanah Kas Desa). TKD ini telah memberikan kas ke pendapatan Asli Desa setiap 6 (enam) bulan sekali yang berupa uang sebesar 2.500.000 hal ini diberikan ke Pendapatan Asli Desa setiap selesai panen. Menurut data yang berhasil dikumpulkan dari awal tahun 2020 hingga pertengahan tahun 2021 yaitu Pendapatan Asli Desa telah menerima kas sebesar 9.500.000, jika

\section{Al-Muqayyad}

Vol 4 No 2 (2021) 
diperinci lagi RP 2.000.000 dari bagi hasil usaha BUMDes dan sisanya itu dari Tanah Kas Desa yang disewakan ke Masyarakat selama satu tahun setengan.

\section{Integrasi}

Salah satu indikator untuk mengukur efektivitas suatu program adalah Indikator Integrasi. Menurut indikator ini, organisasi dikatakan efektif apabila mampu mengadakan sosialisasi atau komunikasi dan pengembangan konsensus. Lebih tepatnya, Integrasi itu menyangkut proses sosialisasi, dan partisipasi masyarakat.

Dalam hal ini, BUMDes Sataretan Desa Soddara ini sudah mampu melakukan integrasi dengan baik dengan cara mengadakan sosialisasi secara menyuluh kepada lapisan masyarakat melalu kepala dusun. Selain itu, tingkat partisipasi masyarakat juga cukup tinggi. Ini dibuktikan dengan adanya kelompok UMKM SDS (Soddara Dhelem Sataretanan) yang memproduksi produk olahan dari masing-masing dusun di Desa Soddara Kec. Pasongosongan Kab. Sumenep.

\section{Adaptasi}

Indikator Adaptasi bertujuan mengukur kemampuan organisasi untuk menyesuaikan diri dengan lingkungannya. Berkaitan dengan kesesuaian pelaksanaan program dengan keadaan di lapangan serta sumber daya manusia.

Dalam aspek Adaptasi BUMDes Sataretanan Desa Soddara masih belum efektif. Dari banyaknya potensi desa yang ada, baru sebagian kecil yang bisa diberdayakan. Begitu juga dengan kemampuan SDM untuk mengelola yang belum profesional sehingga tidak mampu merumuskan dan merealisasikan manajemen bisnis dengan baik. Bahkan BUMDes Sataretan ini juga belum menemukan komposisi yang tepat untuk memproduksi produk yang layak dipasarkan. Produk yang sudah ada masih belum memenuhi kriteria kelayakan produk.

\section{SIMPULAN}

Berdasarkan pembahasan diatas dapat disimpulkan: Pertama, strategi pengelolaan yang dilakukan oleh BUMDes Sataretanan Desa Soddara Kecamatan Pasongsongan Kabupaten Sumenep antara lain: Mengadakan pertemuan rutin anggota internal BUMDes untuk mengevaluasi seluruh perkembangan Program Pengelolaan BUMDes Sataretanan, Membentuk kelompok usaha dari masing-masing dusun yang tergabung dalam kelompok usaha SDS (soddreh delem sataretanan), Mengadakan pelatihan kewirausahaan dan pendampingan produksi produk, Menjalin kerjasama dengan DPMD, Dinas pertanian dan perkebunan, Disperindag dan disnakertran, Kedua, Efektivitas pengelolaan BUMDes Sataretanan dalam meningkatkan Pendapatan Asli Desa Soddara Kecamatan Pasongsongan Kabupaten Sumenep belum efektif karena belum memenuhi semua indikator efektifitas. Dari tiga indikator yang dijadikan pisau 
Efektivitas Pengelolaan BUMDes Sataretanan dalam Meningkatkan Pendapatan Asli Desa

analisis yaitu pencapaian tujuan, integrasi dan adaptasi, hanya satu yang dapat dipenuhi yaitu indikator integrasi.

\section{REFERENSI}

Agunggunanto, Edy Yusuf, Fitrie Arianti, Edi Wibowo Kushartono dan Darwanto. (2016). Pengembangan Desa Mandiri Melalui Pengelolaan Badan Usaha Milik Desa (Bumdes). Jurnal Dinamika Ekonomi dan Bisnis, 13(1).

Amnan, Annisa Riski, Herman Sjahruddin dan Hardiani. (2019). Pengaruh Alokasi Dana Desa dan Pendapatan Asli Desa Terhadap Belanja Desa. Researchgate, 1

Arlan, Agus Sya'bani. (2019). Efektivitas Program Pengelolaan Badan Usaha Milik Desa (Bumdes) Di Desa Ayunan Papan Kecamatan Lokpaikat Kabupaten Tapin. Al'iidara Balad, 2(1).

Ernawati, Sri, Masithah Akbari dan Siti Munawaroh. (2021). Bimbingan Tehnik Penyusunan Profil Bumdes Maju Jaya Desa Sumber Makmur Kec. Takisung Kab. Tala. EPrint. Sekolah Tinggi Ilmu Ekonomi Indonesia Banjarmasin Banjarmasin.

Faedlulloh, Dodi. (2018). BUMDes dan Kepemilikan Warga: Membangun Skema Organisasi Partisipatoris. Journal of Governance, 3(1)

Lestari, Ayu. (2021). Efektivitas Pengelolaan Badan Usaha Milik Desa dalam Pemberdayaan Masyarakat di Desa Buntuna Kecamatan Baolan Kabupaten Tolitoli. Tolis Ilmiah: Jurnal Penelitian, 3(1).

Putra, Asqul Yama. (2017). Strategi Manajemen Aset Bumdes Dalam Meningkatkan Pendapatan Asli Desa Sebagai Penguatan Ekonomi Desa (Studi pada Bumdes Maju Makmur di Desa Minggirsari, Kecamatan Kanigoro, Kabupaten Blitar).

Skripsi. Jurusan Akuntansi Fakultas Ekonomi Dan Bisnis Universitas Muhammadiyah Malang.

Ramadana, Coristya, Berlian, Heru Ribawanto, dan Suwondo. (2013). Keberadaan Badan Usaha Milik Desa (Bumdes) Sebagai Penguatan Ekonomi Desa (Studi di Desa Landungsari, Kecamatan Dau, Kabupaten Malang). Jurnal Administrasi Publik, 1(6).

Suwecantara, Made, Iman Surya, dan Gunthar Riady (2018). Pendapatan Asli Desa Studi Kasus Bumdes Madani Di Desa Santan Tengah Kecamatan Marangkayu Kabupaten Kutai Kartanegara. E-Journal Pemerintah Integratif, 6(4).

Suwecantara, Made, Iman Surya, dan Gunthar Riady. (2018). Efektivitas Pengelolaan Badan Usaha Milik Desa Dalam Meningkatkan Pendapatan Asli Desa Studi Kasus Bumdes Madani Di Desa Santan Tengah Kecamatan Marangkayu Kabupaten Kutai Kartanegara. Ejournal PIN, 6(4).

\section{Al-Muqayyad}

Vol 4 No 2 (2021) 